\title{
How Alzheimer's took toll on my Ba's life and the lives around him
}

\section{Shakya S}

Selika Shakya, MBBS II Year, $20^{\text {th }}$ Batch, Kathmandu Medical College Teaching Hospital

\section{BACKGROUND}

y grandfather $(\mathrm{Ba})$ is of age 83 and around three 1 years back, he was diagnosed with Alzheimer's disease. Today he is lean and thin and spends most of his time in his room, most probably sleeping. He has lost track of the time that he is living in. He has also lost most of his cognitive functions. He can't speak properly, nor is he able to form proper sentences. The state of his neuro degeneration is progressing rapidly.

Ba wasn't like this before. I remember him as a man of pride and independence. He used to be a carpenter who worked day and night to support his family. His work was an art. I can proudly say that the windows and doors of my home were carved and designed by my Ba. Even in a senile age, he wasn't someone who'd stay put at one place and do nothing. Now Alzheimer's has left him weak and lifeless. Today, a man who'd work really hard is left in a corner in a room, without the consciousness of time or place.

\section{PROGRESSION}

The symptoms of Alzheimer's hit my Ba almost a decade ago. I witnessed it by myself. First was dementia. The starter was not much of a big deal really. I mean everybody forgets when they grow old, right? And that's what I thought too. Every now and then Ba would forget where he'd kept his watch or where he'd left his keys. This went on for a few years. It started getting problematic when Ba's personality changed completely and that was a shocker to all the members of my family. The man who once loved the company of his grandchildren has now started doubting the trust of his family. Ba became overly insecure about his money and he constantly thought of being robbed. He would check his savings every day, he'd count every penny. Then he'd forget about it the next day and so recheck it all over again. His obsession

Address for correspondence

Selika Shakya

MBBS 2nd Year

E-mail: selikashakya@gmail.com about money got to such an extent that one day when he forgot where he'd kept his money bag, he became very cross and even blamed us for stealing. Having witnessed all this I'd say that Alzheimer's is a terrible disease. The problems didn't end here. When the disease progressed, Ba's memories started deteriorating further. He would not only forget but also lose track of time as well. He'd forget that he'd already taken his meals and would demand a meal for the second time.

Another symptom that markedly progressed along with dementia was insomnia. I remember waking up to Ba's footsteps at 2.00 in the morning. Ba would periodically wake up at 2 or 3 in the morning and he usually had a hard time falling asleep after that. He'd then spend the time roaming around the house, going up and down the stairs continuously until 5.00 in the morning and finally fall asleep. As I am a light sleeper, I had a hard time falling asleep when Ba was awake and moving about so I had numerous sleepless nights.

The reason for my sleepless nights was not just because Ba was an insomniac. It was also because he'd sometimes be hallucinating!!! The main cause of his hallucinations might have been one of those side effects of the antipsychotic drugs that had been prescribed by his doctor. I still remember the day when I was scared to death by Ba. Like always I generally woke to Ba's footsteps. But this time instead of roaming around the corridors and stairs, he banged the door of my room. It was 2.00 in the morning and I was half asleep. I went to answer the door and when I opened it, Ba asked me if I'd seen a little boy. I was all confused and asked him who he was talking about because surely there were no little boys in our family as I was the youngest. He then said that he'd brought a little boy home that day and until recently that boy was in his room and he had suddenly disappeared. Now a story like that- even a fake one, sounded scary at 2.00 in the morning. It took a few hours to convince him that there was no boy in his room in the first place. I slept with my lights on the rest of the night after that incident. 
Further progression of the disease became marked about two years ago when he started having difficulty recognizing people. It's heartbreaking to say that I was the first family member that he started forgetting. It was when I started my MBBS in Kathmandu Medical College and I had to stay in the hostel. It meant that I had very little time to be around $\mathrm{Ba}$ and so he slowly started to forget me. The patients of Alzheimer's have retrograde amnesia. It was fairly true for Ba. Somewhere in his mind he knew that he had a granddaughter but he just didn't recognize that it was me. Then as the days passed his memories worsened and finally, the only person he remembered was his son, my dad.

As Ba struggled with his memories, dad thought it'd be too dangerous for him to go outdoors so since then $\mathrm{Ba}$ has been kept inside the house. If he has to go out, someone has to accompany him so that he wouldn't get lost. Ba used to go to temples for prayers but he has stopped doing that now. These days all he does is sleep. Sometimes he forgets where he is and in the middle of the night, he insists on going home when he is actually at home. He doesn't really recognize anyone in the family now. Everybody is like a stranger to him. So sometimes he gets insecure around us, like one usually feels around strangers. Every now and then we try to explain to him about our relationships but all that is in vain. He has no memory of the last five or six decades leaving a void in his memories.

The disease hasn't just affected Ba's life. It has taken toll on our lives too. My parents have to constantly worry about Ba's deteriorating health condition, his sanitation, medication and so on. Not a day passes by without discussion over him and his current health status for my parents. As for me, I feel helpless being a medical student, I can't do anything to help Ba or anyone else in my family to feel better. Every time I go home there is a sad atmosphere within the house. My parents try hard so that my brother and I wouldn't be so burdened about Ba's condition. However behind their façade I can feel the pain that they must be going through. I also try hard to cover up my desperation but every now and then, I'm anguished by subconscious thoughts like, 'Why can't I be of some help? What am I studying medicine for?? Isn't there really anything that I could actually do for Ba?', the answer to my questions usually being a negative one.

I usually wonder how Ba's life would've been if he didn't have a neurodegenerative disease, probably better than what it is now. He doesn't have any other health problems, no hypertension or cardiovascular disease or diabetes or gastrointestinal or renal problems. It's ironical to say that he is such a healthy man but with a continuously progressing brain disease. Still, what would he have been doing if he hadn't forgotten the world around him? If only he knew that he was surrounded by his loved ones who he cared for. If only he knew that we were his family, if only. The bitter truth is that he will never remember. But if all this was one scary nightmare of mine and that Ba never had Alzheimer's then, he probably would've been gathering us children in the room to talk about what he always talked about- his glorious days, his work of art, his travels and companions, his days of youth, his life. 